[334]

\title{
A Study of Increased Rice Import Demand in Nigeria: Measuring the Impact of Economic Growth and Changes in Policy
}

\author{
Ogazi, Chinyere Grace*
}

\section{ナイジェリアにおけるコメの輸入需要増加に関する研究：政策変化と経済成長の測定}

\author{
オガジ チンイエーレ グレース（京都大学大学院農学研究科）
}

1996 ～ 2005 年間にナイジェリアのコメ輸入は 3 倍以 上も増加した。その背後には, 国民経済成長, 国際市 場への統合のほか, WTO 協定を遵守するための国内補 助金の削減などの政策があるが, 増え続けるコメの輸 入は, アフリカの中で人口が最も密集するこの国の食 料自給を脅している

そこで本研究は，FAO が提供した $1972 ２ 005$ 年間 の年次データを使って, 同国のコメ輸入需要関数を推 定し, 米輸入の所得・価格弾力性のほか, 同国の貿易 政策, 特に近年の国際市場への統合の影響などについ て分析した。この実証的分析では, 誤差項が自己回帰 過程を持つ一般化最小二乗法, 部分調整ラグモデルの 2 種類の推定方法を用いた.

\section{Introduction}

Nigeria is the largest rice producing country in West Africa. Rice production rose gradually over the years to surpass major rice producing countries in the subregion. Nigeria also accounted for nearly $44 \%$ of the total rice output and $57 \%$ of the total rice producing area in West Africa (WARDA 1996). The country produces about 3.8 MMT of rice and consumes about 6.2 MMT. On the other hand, Nigeria is also a major player in the world rice market and the largest importer in Africa, accounting for $25 \%$ Africa's rice import [4].

Over the years, rice imports into the country have been used to offset domestic shortfalls and domestic rice

* Graduate School of Agriculture, Kyoto University
部分調整ラグモデルで算出された短期価格弾性は -0.143 , 短期と長期所得 (GDP) 弾力性はそれぞれ 0.428 と 0.526 , 短期都市人口弾力性は 1.097 , 長期都市人口 弾力性は 1.348 , 調整係数は 0.186 で, ともに $5 \%$ 水準で 統計的に有意であった。調整係数に基づいて計算され た長期価格弾力性は - 0.164 である。また, WTO 後の補 助金削減政策ダミ一の係数は 0.403 で，5\%の水準で統 計的な有意性が認められた。

要約すれば, 最終的な政策目標は, 輸入制限に限られ るべきではなく，持続的な経済成長の維持や国内の米 生産の強化，そして不安定な世界米市場と対抗し，そ の影響を緩和できる効率的な国内米流通システムの構 築への戦略変更を同時に進めるべきである. supply prospects could depend largely on the sustained growth for imported rice. However, based on the population growth rate, rural-urban migration and rising income, the consumption of rice will continue to grow. The immediate question is how will this growth be met? The simple answer is that rice consumption growth can only be met through increased domestic supply or through import, and both have different ramifications for the economy. If rice import growth should continue, it means, proportion of imported rice consumed in the country will be greater than domestic supply. This will not only decrease self-sufficiency, but will also reduce research initiatives and farmers' enthusiasm to give national research breakthroughs a trial.

A worrisome phenomenon is that Nigeria has comparative resource advantage in rice production at 
least to self-sufficiency, but the continuous growth of import and value over the recent years remains a great concern, particularly how demand and supply changes in the near future. However, in response to the continuing demand for imported rice, the Nigerian government has embarked on several policy reforms, ranging from quantity restriction, ban, tariff, and liberalization. Similarly, prior to 1997 , the government strategy to maintain rice self sufficiency level has been through direct support to producers by providing fertilizer subsidies to farmers and consumers through price controls, now having complied with WTO trade agreements, these subsidies have been dismantled, and the country faces new challenges of sustaining a viable rice industry to meet national self-sufficiency targets.

Furthermore, while trade liberalization is considered as an important stimulus for the expansion of smallholder based on productions targeting global markets, an increasing attention has been given to its impact on small holders' competitiveness in domestic markets [16]. In the same way, OXFAM [17] has viewed rice import expansion in many West African countries to have adverse effects on small holders' livelihoods. The economic reform policy is expected to have an effect on imports, as a part of the strategy to restore external balance, this policy decision is harmful to agricultural development in many developing countries and Nigeria in particular.

In Nigeria, several studies have been undertaken to examine import demand for food products; Olayide [18] estimated the determinants of imports of selected food commodities in Nigeria and found that terms of trade, real income and the index of trade restriction are good parameter estimates. Udoh et al. [9] estimated the demand for food commodities in Nigeria using OLS estimation method. Their results revealed that domestic production; Gross Domestic Product; terms of trade; external reserves and Structural Adjustment Programme (SAP) were the major demand shifters and each factor had inelastic relationship with the quantity of import demand. In this context, and despite the importance of rice sector to Nigeria's economy, the demand behavior for imported rice is not well under- stood. The joint effects of price changes, urbanization and other policy related issues have not been empirically investigated.

However, the recent rice import demand studies have been undertaken by Nkang et al. [15] providing good insights on the effect of conventional factors, such as import value and nominal GDP, external reserve on rice import demand in Nigeria. However, the current study departs from the previous study by incorporating share of population living in the urban areas, real prices of imported rice and other policies related issue particularly the possible impact on Subsidy Compliance Policy (SCP) implemented in 1997. The article adds to the current understanding on how subsidy policy and the increasing rural urban migration have affected the country's rice import demand behavior. It also contributes to the debate on the impact of subsidy removal policy on the escalation of rice import demand in many West African countries. More also, is the increasing concern about the country's population growth rate and future food security, understanding rice import behavior would clarify the underlying demand parameters affecting this growing import and will aid in policy targeted toward food security, producers' income and market shares for domestically produced rice. For instance, where rice import demand responds positively to domestic production, efforts to increase its production will not reduce import demand.

The structure of this paper is organized as follows. Next section; A snapshot of Nigeria rice economy, section 3, discusses theoretical and empirical models. The estimated results and discussion are presented in section 4. Section 5 summarizes the conclusion drawn from the study.

\section{Snapshot of Nigeria Rice Economy}

\section{(1) Relevance of Rice to the Economy}

The Nigerian food sub-sector comprises a large array of staple crops, made possible by the diversity of agro-ecological production systems. The most important food crops are; cereals (sorghum, maize, millet, and rice); tubers (yam and cassava); oil crops, pulses and others (fruits and vegetables). These commodities 
Table 1. Changes in per-capita food consumption pattern in Nigeria from 1960-2005 (kg)

\begin{tabular}{|c|c|c|c|c|c|}
\hline Food crops & $1960 \mathrm{~s}$ & $1970 \mathrm{~s}$ & $1980 \mathrm{~s}$ & $1990 \mathrm{~s}$ & 2000-2005 \\
\hline \multicolumn{6}{|l|}{ Grain crops } \\
\hline Maize & 13 & 9 & 17 & 30 & 21 \\
\hline Millet & 39 & 36 & 30 & 35 & 34 \\
\hline Sorghum & 55 & 37 & 39 & 41 & 40 \\
\hline Rice & 3 & 11 & 24 & 31 & 35 \\
\hline Wheat & 3 & 10 & 11 & 9 & 17 \\
\hline \multicolumn{6}{|c|}{ Tuberous crops } \\
\hline Cassava & 93 & 93 & 85 & 148 & 117 \\
\hline Yams & 44 & 44 & 35 & 70 & 73 \\
\hline \multicolumn{6}{|c|}{ Others food crops } \\
\hline Oil crops & 7 & 5 & 5 & 6 & 7 \\
\hline Pulses & 6 & 6 & 5 & 9 & 9 \\
\hline Vegetables & 50 & 47 & 42 & 50 & 57 \\
\hline Fruits & 67 & 69 & 63 & 65 & 62 \\
\hline
\end{tabular}

Source: Originated from FAO and USDA data.

are important for food security, expenditures and incomes of households. However, among all these food commodities, rice has risen to a position of preeminence [19]. This is because it is the most consumed crop in Nigeria today. Contrarily, in the 1960s, rice was considered as a luxury food consumed mostly in affluent homes and also during religious festivities, now a staple, accounting for more than $25 \%$ of cereal consumption in Nigeria.

Table 1 shows changes in per-capita food consumption pattern in Nigeria from 1960 to 2005. In 1960s quantity of rice consumed was just $3 \mathrm{~kg}$ per-capita. However in 1970s, sorghum, maize and millet percapita consumption declined; in contrast, per-capita rice consumption increased. Increased in per-capita rice consumption has less impact on the tuberous crops in 1970 s, but in the 1980 s per-capita consumption of both yam and cassava declined from $93 \mathrm{~kg}$ and $44 \mathrm{~kg}$ to $85 \mathrm{~kg}$ and $35 \mathrm{~kg}$ respectively. However, the consumption of these crops resumed again in the 1990s as a result of rice importation ban between 1986 and 1993, this fostered the consumption of other grains and tuber crops. The per-capita consumption of these crops dropped again between 2000 and 2005. On the contrarily, rice consumption has been on increase since 1970s. According to Akpokoje et al. [12], since mid 1970s, rice consumption in Nigeria has risen tremendously, at about $10.3 \%$ annually, as result of accelerating population growth rate $(2.8 \%)$ and increasing per-capita consumption (7.3\%). Domestic production has also expanded during the same period at $9.3 \%$ annually, particularly because of area expansion (7.9\%) annually and to a lesser extent through increases in rice yield (1.4\%).

In West Africa, Nigeria cultivates and produces more than half of the cultivated area and output of rice. Nigeria equally imports rice more than the other countries combined. With rising income and increasingly rural urban migration, the average growth rates in per capita rice consumption are bound to rise. According to Diagana et al. [2], Kennedy and Reardon. [10] and Reardon [20], rice diet transition was supported by income growth and urbanization. The diet transition has shifted urban consumer's preferences in favor of a product that can be easily cooked, to the expense of coarse grains and tuber crops that required more time to be prepared, thus making rice a strategic commodity in West Africa. Similarly, Lançon [11], argues that the rapid increase of rice import are more related to structural changes in consumers' behavior induced by a continuous increase of per capita income in a society that become radically more urban in its way of living and left gradually behind a diet inherited from rural areas. The combination of increasing rural urban 
migration, income growth in synergy with the increasing availability of imported rice could have brought the average urban population to pass a threshold and to accelerate their transition to a rice diet. Rice is easy to prepare when compared to traditional food crops, thereby reducing the chore of food preparation and fitting easily the urban lifestyles of rich and poor alike.

Similarly, the World Bank cited in FAO report, that rice is no longer a luxury food in Nigeria, and that it has become a major source of calories for the urban poor. Adding also that the poorest third of urban households obtained $33 \%$ of their cereal-based calories from rice, and rice purchases represent a major component of cash expenditures on cereals. Consequently, the Nigerian government has been concerned with rice, for good reasons. First Nigeria's rice self-sufficiency is low, imported rice dominates the urban markets. Secondly, rice is perceived as a food security crop because it is the fastest growing and widely consumed food in Nigeria. The per capita consumption is expected to continue to grow in the coming years. This makes it imperative for the government to show interest on how to make this commodity readily available and affordable.

\section{(2) Domestic Rice Production Policy}

The Nigerian rice policy is motivated by many factors, such as the restriction on unfair competition with imported rice; the pursuit for self-sufficiency and national food security. It also based on poverty alleviation and to raise farmers' income, to reverse the high foreign exchange flows from imported rice; and the desire to raise the nutritional level of the average Nigerian by making rice available at affordable prices. However, these objectives seem unassailable, but government policies on the sector had been incoherent. In many cases, government policies have worked against the nationalistic move for self sufficiency.

Similarly, the slow growth in domestic rice production cannot only be associated with increasing rice imports. The government has actively interfered on the rice sector over the last three decades; rice policy has not been steady, oscillating between high import tariffs, import restrictions, and outright ban. For instance, between 1986 and 1994, rice imports were illegal. In 1995, imports were allowed at $100 \%$ tariff. In 1996 , the tariff was reduced to $50 \%$ and in 2002 , the tariff was returned to $100 \%$. With these various policy measures, domestic rice production has responded but not sufficiently to meet local demand.

Figure 1 show that rice output growth rate increased in the early 1970s, however, between 1975 and 1976 there was a negative growth rate of both area and output.

Both area and output picked again in 1977 and

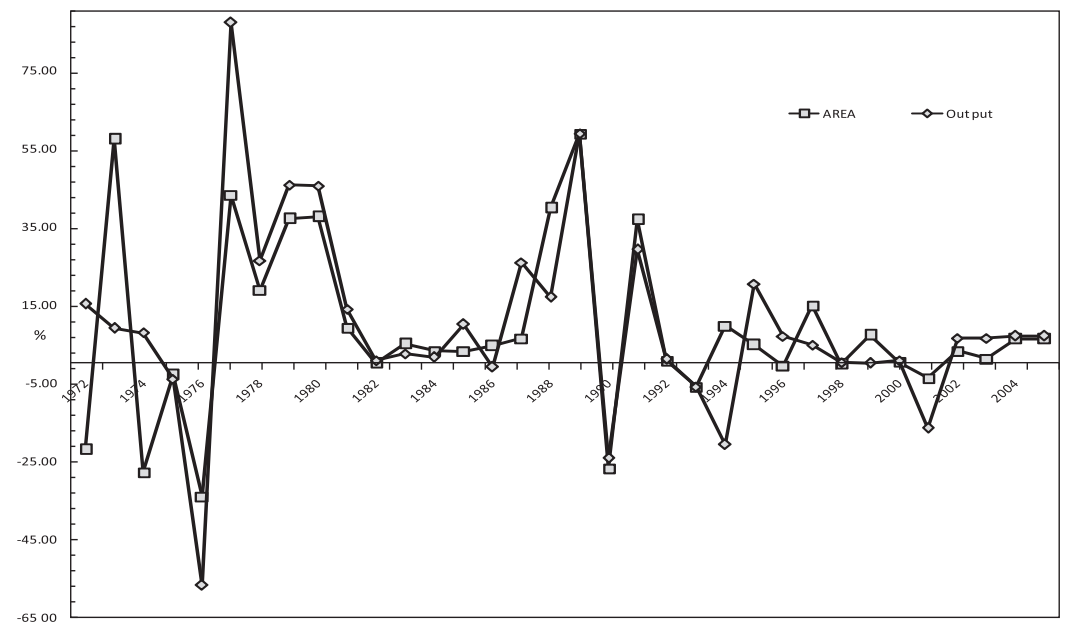

Fig. 1. Growth rate in rice cropped area and production in Nigeria (1972-2005) 
declined in 1990. Another significant decline was observed in 1994, when rice import ban was removed, output and area growth rate declined to $24 \%$ and $27 \%$ respectively. In 2001 rice output rate declined, then increase again in 2002 and remains virtually stagnant until 2005. The stagnant growth rate and the increasing demand for this commodity justifies the overarching need to intervene proactively in domestic production, quality improvement and its competitiveness in the domestic markets.

Another constraint beside policy instability is the rising cost of labor due to rural urban migration. Labor accounts for $50-55 \%$ of the rice production cost. Similarly Ezedinma and Kormawa [4] reported that the most important factor that led to the collapse of farm agribusiness linkages in the major rice producing area of Abakiliki, Southeast Nigeria was the high cost of labor for rice production. Labor became more expensive as a result of massive rural urban migration. The attraction to the cities is due to the discovery of a new lucrative enterprise and alternative off farm employment. Also lack of farm subsidy, no complimentary agricultural policy to support rice farmer and the increasing rice importation has eroded the profit margin of rice farmers.

\section{(3) Rice Import Demand and Growth}

Figure 2 shows that between 1976 and 1984 rice imports increased rapidly, self-sufficiency dropped as a result of high consumption growth rate could not match with domestic production growth rate; rice imports resumed again in 1996. Between 1996 and 2005, rice imports increased rapidly at an average annual rate of $26 \%$.

Changes in rice import levels after 1996 can be characterized on the bases of the concept of "imports surge" as defined by De Nigris [14], whereby a surge occurs if the import volume for a given year is $30 \%$ higher than the average volume recorded in the three previous years. Applying this definition, the first rice imports surge was observed in 1997 when quantity imported increased to $102 \%$ from the previous year. The second was observed in 2001 with $125 \%$ increase and was triggered by several factors. On the domestic side, major staple food supply declined, which caused a rapid increase in the price of traditional staples. Consumers shifted toward rice in order to mitigate the effect of other major staple price increase [21]. More also imported rice was more competitive because of its low price. On the other hand, local rice market share has been decreasing since late 90 s, showing that the

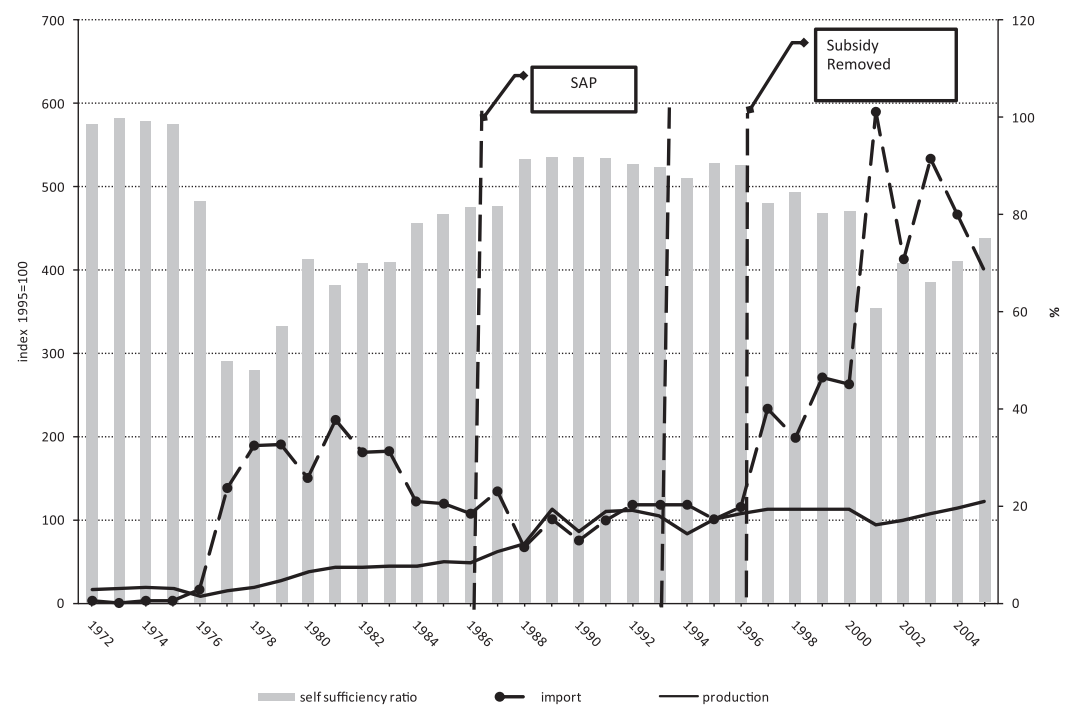

Fig. 2. Importations, production trends index and self reliance ratio $(1972-2005 ; 1995=100)$

Source: FAO 2009. 
bulk of rice consumption had been covered by imports. However, rice imports expansion did not cause a fall in domestic production as shown in Figure 2. The import ban during SAP period, initially stimulated production increase, but has not been efficient to maintain a steady and long-term demand growth. Rice self-sufficiency ratio is the ratio of domestic rice supply to the total demand. Self-sufficiency was adversely affected between 1977 and 1985. In addition, since 1997 selfsufficiency ratio has been on decline implying that import substitution policy has failed to ameliorate rice self-sufficiency in the country.

Furthermore, there is the need to ascertain implications of implementing of the subsidy removal policy in agreement with WTO with the view of generating appropriate domestic policies to promote rice production. However, given the competitive and liberalized world economy, the demand for economic, social and political stability as well as meeting the challenge of food security, Nigeria faces strategic choices in relation to the rice sector development.

\section{Methodology}

\section{(1) Theoretical and Empirical Models}

Various models have been developed to estimate import demand of agricultural commodities; Rosson et al. [5] estimated import demand determinants for apples, poultry, and tobacco; Lanclos et al. [7] investigated import demand for U.S. frozen potatoes; and Le et al. [6] studied import demand for U.S. red meat products into four Pacific Rim countries. Most of these studies shows that a negative and significant relationship exist between import quantities and trade barriers. Export promotion programs for agricultural commodities often end up in fostering higher levels of imports particularly non-traditional staples.

This study therefore, assumes that rice-import demand function can be specified as follows:

$$
Q I_{t}=e^{\delta_{0}}\left(\frac{P_{f_{t}} E_{t}}{P_{d_{t}}}\right)^{\delta_{1}} P G D P_{t}^{\delta_{2}} P D S_{t-1} \delta_{3} U R B_{t}^{\delta_{4}}
$$

Where $Q I$ represents per-capita quantity of rice imported in metric tons (MT). $P_{f}$ is the foreign price in
US dollars, $P_{d}$ is the index of consumer prices. $E$ is the nominal exchange rate and $R G D P$ is real per-capita Gross Domestic Product measured in Naira. $P D S_{t-1}$ is one year lagged per capita domestic rice supply, and $U R B$ is urban share of the total population and $\mathrm{t}$ is time trend. $\delta_{0}, \delta_{1}, \delta_{2}, \delta_{3}$ and $\delta_{4}$ are the coefficients to be estimated.

The natural logarithm of the above equation is express as follows;

$$
\begin{aligned}
\ln Q I_{t}= & \delta_{0}+\delta_{1} \ln P R_{t}+\delta_{2} \ln P G D P_{t} \\
& +\delta_{3} \ln P D S_{t-1}+\delta_{4} \ln U R B_{t}
\end{aligned}
$$

Where $R P$ is the real import prices $\left(\frac{P_{f_{t}} E_{t}}{P_{d_{t}}}\right) \delta_{0}$ represent the coefficient of intercept, $\delta_{1}, \delta_{2}, \delta_{3}$ and $\delta_{4}$ are the short run elasticities, $\mu_{t}$ is the error term assumed to have a mean of zero and constant variance.

Furthermore, one of the main features of this study is to measure possible changes in the import demand during SAP and the possible impact of the subsidy removal policy on rice import growth in Nigeria by the use dummy variable. SAP was adopted to reduce disequilibrium arising from food importation in the country and to strengthen the domestic food production capacity. During SAP period, it was illegal to import rice into the country. This was done to encourage domestic rice production. Similarly, while implementing the structural adjustment programs in the late 1980s, many developing countries particularly Nigeria started the process of phasing out subsidies for two reasons: failure of the subsidy scheme to "mature" into efficient behavior as directed by the world Trade Organization and unsustainable budgetary cost of subsidies. The SCP was implemented in the early 1997 and since then rice-import growth increased rapidly as shown in figure 2 . In 2003, the Nigerian government passed a bill authorizing 50\% subsidies on inputs to alleviate food shortage. The impact of SAP and SCP are hypothesized to carry over for a period of time, it is plausible to model rice-import demand function that allows the impact of SAP and SCP. In this study, DSAP is a dummy for SAP, which takes one during the adjustment period and zero otherwise. DSCP is a dummy variable for SCP, which 
Table 2. Descriptive statistics of variables used in the rice-import demand function, 1972-2005

\begin{tabular}{lccrrrr}
\hline \hline \multicolumn{1}{c}{ Variable } & Notation & $\begin{array}{c}\text { Unit of } \\
\text { Measurement }\end{array}$ & Mean & $\begin{array}{c}\text { Standard } \\
\text { Deviation }\end{array}$ & Min & Max \\
\hline Quantity Imported & $Q I$ & Tons/cap/yr & 6.73 & 3.41 & 0.77 & 15.26 \\
Import Price & $R P$ & Naira/tons & 17.58 & 11.30 & 0.20 & 42.60 \\
Domestic Supply & $P D S$ & Tons/cap/yr & 19.04 & 8.35 & 3.12 & 34.20 \\
Per-capita GDP & $P G D P$ & Naira/cap/yr & 390 & 101 & 251 & 657 \\
Urban share of the total Population & URB & Percentage & 33.71 & 7.30 & 22.70 & 46.33 \\
\hline
\end{tabular}

All financial data are deflated with Consumer Price Index $(2000=100)$.

takes a value of one when subsidy was removed and zero otherwise.

Using the import demand model, presented in equation 2, the rice import function that also allows for the effects of these two dummies on rice-import demand in Nigeria can be expressed as:

$$
\begin{aligned}
\ln Q I_{t}= & \delta_{0}+\delta_{1} \ln P R_{t}+\delta_{2} \ln P G D P_{t}+\delta_{3} \ln P D S_{t-1} \\
& +\delta_{4} \ln U R B_{t}+\delta_{5} D S A P+\delta_{6} D S C P+\mu_{t}
\end{aligned}
$$

Although the direct estimation of the equation (3) is not the main purpose of this paper, just in case, the estimated result is shown in the left side of Table 3. Furthermore, the import demand specified in equation 3 , may be incorrect in several ways. First, past import levels may affect future import patterns. Secondly, shift in consumer's tastes may affect the slope and the position of the rice-import demand curve. Thirdly, time lags and logistic delays in production, importation and distribution may affect its availability.

Thus, to overcome these limitations, lagged dependent variables are added to the ordinary rice-import demand function, which can be extended to Partial Adjustment Model. The Partial Adjustment Model assumes that the economic agent partially corrects the gap between the desired and actual values in the previous year. The equation defining the desired values is defined as follows;

$$
\ln Q I_{t}-\ln Q I_{t-1}=\gamma\left[\ln Q I_{t}^{*}-\ln Q I_{t-1}\right]
$$

Where $Q I_{t}{ }^{*}$ represents the desired per-capita rice import demand and $Q I_{t}$ is the actual per-capita rice import demand $0 \leq \gamma \leq 1, \gamma$ is the adjustment coefficient, which measures the adjusted portion of the difference between the desired value $Q I_{t}{ }^{*}$ and the realized value
$Q I_{t-1}$. When $\gamma=1$ the current value of $Q I_{t}$ is equal to its desired value $Q I_{t-1}{ }^{*}$ which means that the adjustment is total and immediate. If the adjustment coefficient is close to zero, then it takes longer time to adjust completely. For this model, the left hand side of the equation (3) should be changed to be $\ln Q I_{t}{ }^{*}$ instead of $\ln Q I_{t}$ and the error term should be deleted because this is not the estimation formula but the definition in this case. Substituting $\ln Q I_{t}{ }^{*}$ of the changed equation (3) into equation (4) and simplifying yields equation (5):

$$
\begin{aligned}
\ln Q I_{t}= & \delta_{0}+\delta_{1} \ln P R_{t}+\delta_{2} \ln P G D P_{t}+\delta_{3} \ln P D S_{t-1}+\delta_{4} \ln U R B_{t} \\
& +\delta_{5} \ln Q I_{t-1}+\delta_{6} D S A P+\delta_{7} D S C P+\mu_{t}^{\prime}
\end{aligned}
$$

The coefficient of each explanatory variable directly gives short run elasticities. The long-run elasticities can be calculated by dividing $\delta_{1} \ldots \ldots \delta_{5}$ by one minus the coefficient of lagged per-capita quantity of rice import demand $\left(1-\delta_{5}\right)$. The assumption underlying this model is that all the long run elasticities exceed short run elasticities. Given the importance of elasticities for policy analysis and the fact that no distinction can be made between the long run and the short run in the ordinary import demand model, the Partial Adjustment Model is used to estimate these parameters in the next section.

\section{(2) The Data and Sources}

Data come from different sources. Rice import price and quantity imported are sourced from the FAO and United States Department of Agriculture (USDA). The nominal exchange rates (Naira) per US dollar, percapita GDP, index of consumer's prices and demographic variables are obtained from International Financial Statistics. Rice imported quantity comprised (milled, broken and husked). The sample period covers 
Table 3. Estimated Results of Rice Import demand in Nigeria 1972-2005

\begin{tabular}{|c|c|c|c|c|c|}
\hline \multicolumn{3}{|c|}{ Ordinary rice Import Demand Equation (3) } & \multicolumn{3}{|c|}{ Partial Adjustment Model Equation (5) } \\
\hline Variable & $\begin{array}{l}\text { Parameter } \\
\text { Estimates }\end{array}$ & $\begin{array}{l}\text { Standard } \\
\text { Error }\end{array}$ & $\begin{array}{l}\text { Parameter } \\
\text { Estimates }\end{array}$ & $\begin{array}{l}\text { Standard } \\
\text { Error }\end{array}$ & $\begin{array}{l}\text { Long Run } \\
\text { Elasticities }\end{array}$ \\
\hline $\mathrm{RP}$ & $-0.172^{* *}$ & 0.066 & $-0.143^{* * *}$ & 0.043 & -0.176 \\
\hline PGDP & $0.540^{*}$ & 0.279 & $0.428^{*}$ & 0.236 & 0.526 \\
\hline $\mathrm{PDS}_{\mathrm{t}-1}$ & $-0.363^{*}$ & 0.208 & -0.301 & 0.187 & -0.370 \\
\hline URB & $1.235^{* *}$ & 0.607 & $1.097 * *$ & 0.545 & 1.348 \\
\hline DSAP & -0.167 & 0.176 & -0.139 & 0.145 & \\
\hline DSCP & $0.504^{* *}$ & 0.174 & $0.403^{* *}$ & 0.162 & \\
\hline CONSTANT & $4.303^{* * *}$ & 1.105 & $3.601^{* * *}$ & 1.064 & \\
\hline $\operatorname{AR}(1)(\rho)$ & 0.306 & 0.218 & & & \\
\hline $\mathrm{QI}(-1)$ & & & $0.186^{*}$ & 0.107 & \\
\hline $\mathrm{R}^{2}$ Adjusted & 0.775 & & 0.765 & & \\
\hline DW & 2.142 & & $\begin{array}{l}\text { Durbin h-stat } \\
\quad=0.5025\end{array}$ & & \\
\hline
\end{tabular}

*** Significant at $1 \%, * *$ significant at $5 \%$ and $*$ significant at $10 \%$.

yearly data from 1972 to 2005. The descriptive statistics are presented in table 2 .

\section{Estimation Results and Discussion}

Table 3 presents result from the estimated of rice import demand equation. The 1st-3rd columns show the estimates from the original import demand model. The 4th-6th columns show the estimates obtained from Partial Adjustment Model. The $\mathrm{R}^{2}$-adjusted (goodness-of-fit measure) explain about 0.77 in both estimated results. The Hypothesis testing for overall significance of the regression using the F-test indicated that there is a significant relationship between per capita rice import quantity and the explanatory variables for both models. The Durbin h-statistic values suggest the acceptance of the hypothesis that there is no serial correlation. All the estimated parameters have sign consistent with economic theory and priori expectations. Almost all parameters were statistically significant at $10 \%$ level except DSAP and $P D S_{t-1}$ in the Partial Adjustment Model. However, $P D S_{t-1}$ is statistically significant at $10 \%$ in ordinary import demand equation.

The coefficient of lagged per-capita rice import quantity is positive and statistically significant at $10 \%$; the coefficient of adjustment $(\gamma)$ is 0.81 . This value indicates that there is a high adjustment process between the current per-capita import quantity demand and desired long run per-capita import demand. Given the relatively high adjustment process, the difference between the short-run and long run elasticities can be justified. In general, the long-run elasticities are larger than the short-run elasticities by reasonable proportion.

Coefficient of relative price of rice is significant at $1 \%$ but inelastic. This suggest that an increase in the import price of rice, holding price constant, would lead to a decrease in import demand for rice but at a lesser magnitude. This results support the findings by the several previous studies that have estimated inelastic price elasticities of import demand for agricultural commodity. The elasticity of the real percapita GDP variable is 0.428 , positive and significant at a $10 \%$ level, this elasticity suggests that a $10 \%$ increase in real per-capita GDP will increase import demand for rice by $4.3 \%$. A negative coefficient of per-capita domestic rice supply suggests that rice imports adjust in with changes in per-capita domestic rice supply. As has been pointed out in the literature, substitution relationship between domestic supply and imports will mean that measures to decrease or reduce the imports will lead directly into increase demand for domestic rice. The coefficient of urbanization variable is statistically significant at $5 \%$ with a 
very high magnitude, indicating that the variable has an over whelming impact on rice import growth in the country. The significant positive sign of urbanization is consistent with the findings reported by Diagana et al. [2], Kennedy and Reardon [10], and Reardon [19] previous studies on rice import demand growth in West Africa.

The coefficient of DSAP has expected negative sign, but not statistically significant. The reasons for nonsignificance could be that the policy time frame is short. The coefficient DSCP is statistically significant at 5\% level; indicating that implementations of subsidy removal policy positively contributed to the rice import growth during the study period.

This study was further compared with the related study conducted by Nkanga et al. [15], firstly the current study attach weight in the model by using per capita import quantity and domestic supply, as opposed to total import quantity and domestic supply used by the previous study. Secondly, real import price and real per-capita GDP is used as opposed to import value and nominal GDP used by the previous study, thereby reflecting the standard of living and the effects of inflation is factored in. Thirdly, urbanization is used to capture diet transition, declining labor force and changes in life style. The study also explores the impact of subsidy removal policy implemented in 1997 on rice import growth in Nigeria and larger sample size.

\section{Conclusion and Policy Implication}

This study examined the behavior of rice import growth in Nigeria by particularly examining the factors influencing rice import during the period of 1972-2005. The model specification is based on the ordinary import demand model and is extended to Partial Adjustment Model. Equation 3 and 5 were performed respectively with Generalized Least Squares with first-order autoregressive error term (AR (1)) and Partial Adjustment Lag Model. The explanatory power of both equations explains about $77 \%$ variation and the results shows that real per-capita GDP, real import price, urbanization and subsidy removal policy impacted rice-import demand behavior in Nigeria during the studied period.

Although real import price is highly significant, it is inelastic with small magnitude. This implies that, policy actions to reduce rice imports in the short-run could not be feasible by reducing import price. The real per-capita GDP elasticities have the expected sign and are statistically significant implying that imported rice is a normal good, but when compared to many Asian countries, it is relatively high. It also indicates that rice import is related to per-capita GDP growth, and as long as income rises, rice consumption will increase which may lead to increase in rice import. Here, ultimate policy objective should not be confined in containing rice imports but should seek simultaneously to improve economic growth in which rice imports depends upon.

The positive and significant sign of urbanization implies that urbanization has a strong impact on imported rice consumption in the country and as long as urban population increases, all things remaining the same, rice imports are likely to follow the similar trend.

The magnitude of the short run and long-run elasticities indicates that the demand for imported rice will continue to increase in the near future.

The study also examined the impact of import policy on rice import growth. One of the indicators used to assess the impact of policy on rice import growth in Nigeria during the study period is the SAP. It was found that DSAP though not significant at any reasonable level but has expected negative sign indicating that the policy has a negative impact on rice import growth.

Secondly, the response of rice import growth to farmsubsidy removal policy does not come as a surprise, in the light of policy practiced in before undertaking the policy reform. Fertilizer subsidies became popular for both political and economic reasons. Politically, they became an instrument of pleasing farmers in the rural sector, and economically, benefits outweighed the costs of fertilizer subsidies in terms of foreign exchange savings resulting from import substitution. It was found that subsidy compliance policy dummy is statistically significant at $5 \%$. The increases in per-capita income; urbanization and subsidy compliance policy are important factors affecting rice import demand behavior in 
Nigeria during the investigated period.

The major implication here is that if rice import growth is faster than total agricultural export growth in the ongoing process of trade liberalization, an important issue is the sustainability of the trade account deficit that depends on the strength of real exchange rates as a balance of payments adjustment mechanism, and the inflows of foreign capital.

Finally, the food security implication, available data from FAO shows that domestic food production contributes more than $90 \%$ food consumption in Nigeria, and to enhance the country food security, it is imperative to promote polices that will accelerate domestic food production growth particularly rice. Increasing rice production would translate to gradual increase in rice supplies, which will be sufficient for domestic demand and could act as a buffer mechanism against the thinness and volatility of world rice market.

\section{References}

〔1] A. Regmi and J. Dyck, "Effect of urbanization on global food demand" Changing Structure of Global Food Consumption and Trade, Trade Report (WRS 2001-1), pp. 1-8.

〔2〕 B. Diagana, F. Akindes, S. Kimseyinga, T. Reardon and J. Staatz, "Effects of the CFA franc devaluation on urban food consumption in West Africa"; overview and cross country comparison, Food Policy, Vol. 24, No 5 (2000), pp. 465-478.

[3] C.E. Okorji and C. Onwuka, "A comparative analysis of costs and returns of non irrigated and irrigated rice production systems in Uzo Uwani local government area of Enugu State, Nigeria”, Agricultural Systems in Africa, Vol. 4, No. 2 (1994), pp. 5-8.

[4] C.I. Ezedinma and P.M Kormawa, "Farm Agribusiness Linkages in Nigeria", A Report presented to the Agricultural Management, Marketing and Finance Service of the FAO of the United Nations, Rome, Italy (2002), pp. 3-15.

[5] C. Rosson, M. Hammig and J. Jones, "Foreign Market Promotion Programs: An Analysis of Promotion Response for Apples, Poultry, and Tobacco.” Agribusiness, Vol. 2, No. 1 (1986), pp. 33-44.

[6] C.T. Le, H.M. Kaiser and W. Tomek, "Export Promotion and Import Demand for U.S. Red Meat in Selected Pacific Rim Countries", Agribusiness, Vol. 14, No. 2 (1998), pp. $1-25$.

[7] D. Lanclos, S. Devadoss and J. Guenthner, "Impacts of
Foreign Direct Investment and Advertising on the Export Demand for U.S. Frozen Potatoes", Agribusiness, Vol. 13, No. 2, (1997), pp. 273-284.

[8] D. Thomakos and M.A. Ulubasoglu, "The Impact of Trade Liberalization on Import Demand”, Journal of Economic and Social Research, 4, (2002), pp. 1-26.

[9] E.J. Udoh, I.C. Idiong and B.T. Omonona, "Determinants of food imports demand and policy shift in Nigeria", International Journal of Social Science and Public Policy, Vol. 4, No. 2 (2001), pp. 172-177.

〔10] E. Kennedy and T. Reardon, "Shift to Nontraditional Grains in the Diets of East and West Africa: Role of Women's Opportunity Cost of Time”, Food Policy, Vol. 1, (1994), pp. 45-56.

[11] F.O. Lançon, "Rice imports in West Africa: trade regimes and food policy formulation", Pro-poor development in low income countries: Food, agriculture, trade, and environment. Montpellier France (25-27 October 2007), pp. 1-16.

〔12〕 G. Akpokodje, F. Lancon and O. Erenstein, "Nigeria’s Rice Economy: State of the Art”, West Africa Rice Development Association, Bouake, Cote d'Ivoire, (2001), pp. 1-22.

〔13〕 M. Gehlhar and W. Coyle, "Changing Structure of Global Food Consumption and Trade”, (WRS 2001-1) pp. 1-10.

[14] M. De Nigris, "Defining and quantifying the extent of import surges: data and methodologies", FAO Import Surge Project Working Paper, FAO, Rome, (2005), pp. 2-15.

〔15〕 M. Nkang, S.O. Abang, O.E. Akpan and E.O. Edet, "Rice production, import and food security in Nigeria: An application of cointegration and error correction model", Journal of Food, Agriculture \& Environment, Vol. 4, No. 1 (2006), pp. 86-90.

[16] P. Nouhine Diye, G. Duteurtre, J-R Cuzon and D. Dia, "Livestock, liberalization and trade negotiation in West Africa", Outlook on Agriculture, Vol. 36, No. 2, (2007), pp. 93-99.

[17] OXFAM, "kicking downs the door-how upcoming WTO talks threaten farmers in poor countries" (Oxfam International, 2005), pp. 3-16.

[18] S.O. Olayide, "Import demand model: An econometric analysis of Nigeria's import trade", The Nigerian Journal of Economic and Social Studies, vol. 10, No. 3 (1968), pp. 303-319.

[19] T. Akande, "An Overview of the Nigeria Rice Economy", The Nigerian Institute of Social and Economic Research (NISER) lbadan, (2000), pp. 1-38.

[20] T. Reardon, "Cereals Demand in the Sahel and Potential Impacts of Regional Cereals Protection”, World Developments, Vol. 21, No. 1 (1993), pp. 17-35.

[21] USDA-FAS, 2007, Nigeria Grain and Feed Rice Update 2007, GAIN report, NI7004.

（受理日：2010 年 5 月 6 日） 